Vol. 6 (1997): 259-268.

\title{
Influence of sodium and potassium fertilization on the sodium concentration of timothy
}

\author{
Tommi Peltovuori \\ Department of Applied Chemistry and Microbiology, PO Box 27, FIN-00014 University of Helsinki, Finland, \\ e-mail: tommi.peltovuori@helsinki.fi \\ Markku Yli-Halla \\ Department of Applied Chemistry and Microbiology, FIN-00014 University of Helsinki, Finland. Current address: \\ Institute of Resource Management, Agricultural Research Centre of Finland, FIN-31600 Jokioinen, Finland
}

\begin{abstract}
Sodium (Na) concentration of forage crops grown in Finland, particularly that of timothy, is much lower than is recommended in the feed of cattle. A pot experiment was carried out on clay, loam and organogenic soils to find out the effect of Na application $\left(0,200\right.$ or $400 \mathrm{mg} \mathrm{dm}^{-3}$ of soil, one application) on the concentration of $\mathrm{Na}, \mathrm{K}, \mathrm{Ca}$ and $\mathrm{Mg}$ of timothy and the effect of $\mathrm{K}$ fertilization $(0,100$ and $200 \mathrm{mg} \mathrm{dm}^{-3}$ for each three harvests) on the efficiency of $\mathrm{Na}$ application. Added $\mathrm{Na}$ elevated the $\mathrm{Na}$ concentration in all harvests on all soils. The magnitude of the effect (organogenic soil $z$ loam $>$ clay) was opposite to the K supplying power of the soil. Potassium fertilization suppressed the effect of $\mathrm{Na}$ application substantially and $\mathrm{Na}$ concentration was elevated remarkably only when the $\mathrm{K}$ concentration of the plants fell to or below the deficiency level (approximately $15 \mathrm{~g} \mathrm{~kg}^{-1}$ ). According to a cation exchange experiment, nearly all added Na remained in the soil solution. Still, the apparent utilization of added Na remained below $4 \%$ on all soils, demonstrating the natrophobic nature of timothy. Sodium fertilization of timothy seems to be an ineffective way of increasing the Na content of forage at least on soils of a good $\mathrm{K}$ status or when applied with ample $\mathrm{K}$ fertilization.
\end{abstract}

Key words: calcium, cation exchange isotherms, magnesium, mineral composition of forage, pot experiment, selectivity in cation exchange

\section{Introduction}

Sodium ( $\mathrm{Na}$ ) can substitute for potassium $(\mathrm{K})$ in the biophysical functions of $\mathrm{K}$ in most plants, e.g. in regulating osmotic pressure in vacuoles, and to a limited extent in biochemical functions, e.g. in activation of enzymes. However, the ability of Na to substitute for $\mathrm{K}$ varies greatly between plant species (Flowers and Läuchli 1983). Most agronomically significant species like timothy, rye, corn and soybean are natrophobic. In these species Na cannot effectively substitute for $\mathrm{K}$ and the $\mathrm{Na}$ concentration of plants tends to be 


\section{AGRICULTURAL AND FOOD SCIENCE IN FINLAND}

\section{Peltovuori, T. \& Yli-Halla, M. Sodium and potassium fertilization of timothy}

low. The average Na concentration of timothy in Finland (mean $0.047 \mathrm{~g} \mathrm{~kg}^{-1}$, Kähäri and Nissinen 1978) is of the same order as that of the micronutrients $\mathrm{Fe}, \mathrm{Mn}$ and $\mathrm{Zn}$, while in other grasses like cocksfoot $\left(0.3 \mathrm{~g} \mathrm{~kg}^{-1}\right.$, Rinne et al. 1974), and particularly in ryegrass $\left(0.8 \mathrm{~g} \mathrm{~kg}^{-1}\right.$, Jansson 1986), the $\mathrm{Na}$ concentration tends to be higher.

The Na concentration of cereals is relatively unimportant but that of pasture species affects the quality of fodder used for animal production. Sodium is an essential mineral element for animals, and forage should contain $\mathrm{Na} 1.8-2 \mathrm{~g} \mathrm{~kg}^{-1}$ of dry matter to supply milking cows with sufficient Na (NJF 1975, Smith and Middleton 1978, Horn 1988). Thus, there is a big difference between the requirement of cattle and the supply of $\mathrm{Na}$ from farm-produced fodder in Finland, and it has to be compensated with mineral supplements. Another imbalance of mineral elements in fodder is brought about by heavy $\mathrm{K}$ fertilization of leys leading to excessive $\mathrm{K}$ concentration and lower than optimum concentration of other cations, especially magnesium $(\mathrm{Mg})$, in herbage (Smith and Middleton 1978, Leigh et al. 1988). The equivalent ratio $\mathrm{K} /(\mathrm{Ca}+\mathrm{Mg})$ has been used as a criterion for forage grass quality; values below 2.2 are desired (Ettala and Kossila 1979). Substitution of $\mathrm{Na}$ for $\mathrm{K}$ in plants has been shown to increase their $\mathrm{Mg}$ concentration (Nowakowski et al. 1974, Smith 1974, Smith et al. 1980, Mundy 1983). Sodium application can thus improve the feeding quality of herbage by increasing the concentration of $\mathrm{Na}$ and $\mathrm{Mg}$ and possibly by lowering the concentration of $\mathrm{K}$. Elevated $\mathrm{Na}$ concentration of herbage may also increase the intake of fodder by cows (Horn 1988, Chiy et al. 1993), resulting in an increase in liveweight gain and in milk production (Chiy et al. 1993).

The purpose of this study was to examine whether the $\mathrm{Na}$ concentration of timothy can be elevated by $\mathrm{Na}$ application and to find out the effects of $\mathrm{Na}$ application on the uptake of other cations on three different soils. The effect of $\mathrm{K}$ application on the efficiency of $\mathrm{Na}$ fertilization was also studied. The natrophobic nature of timothy and its poor response to added $\mathrm{Na}$ is evi- dent from the literature. Nevertheless, it was selected as the test crop because, owing to its winter hardiness, it is by far the most common pasture species in Finland. The fate of added $\mathrm{Na}$ in soil was also investigated by determining cation exchange isotherms for the cation exchange pairs $\mathrm{Na} / \mathrm{K}$ and $\mathrm{Na} / \mathrm{Ca}$.

\section{Material and Methods}

The effect of $\mathrm{Na}$ on the growth and chemical composition of timothy was studied in a pot experiment. The experimental soils (silty clay, loam and organogenic soil, Table 1) were taken from plough layers of cultivated fields in Southern Finland. In the text, the silty clay will be referred to as clay. The high concentrations of $\mathrm{Ca}$ and $\mathrm{Mg}$ and the relatively high $\mathrm{pH}$ of the organogenic soil are probably attributable to liming.

The soils were air-dried and ground to pass a 10-mm sieve. For chemical analyses, part of the soil was ground further to pass a $2-\mathrm{mm}$ or a 0.6-mm sieve ( $\mathrm{C}$ analysis). The carbon concentration was determined using a LECO CHN-900 analyser. The particle size distribution was determined by a pipette method. The $\mathrm{pH}$ was determined in a $0.01 \mathrm{M} \mathrm{CaCl}_{2}$ suspension at the

Table 1. Properties of the experimental soils.

\begin{tabular}{|c|c|c|c|}
\hline & Clay & Loam O & $\begin{array}{c}\text { Organogenic } \\
\text { soil }\end{array}$ \\
\hline \multicolumn{4}{|c|}{ Particle size distribution, $\%$} \\
\hline$<0.002 \mathrm{~mm}$ & 44.1 & 8.0 & 29.9 \\
\hline $0.002-0.02 \mathrm{~mm}$ & 24.5 & 19.4 & 39.4 \\
\hline $0.02 \mathrm{~mm}<$ & 31.5 & 72.6 & 30.7 \\
\hline Organic C, \% & 3.9 & 2.8 & 26.6 \\
\hline Soil pH $\left(0.01 \mathrm{M} \mathrm{CaCl}_{2}\right)$ & 5.9 & 6.3 & 5.8 \\
\hline \multicolumn{4}{|c|}{ Exchangeable cations, $\mathrm{mg} \mathrm{dm}^{-3}$} \\
\hline $\mathrm{Na}$ & 14.5 & 7.7 & 9.3 \\
\hline K & 283 & 134 & 87 \\
\hline $\mathrm{Ca}$ & 2207 & 1520 & 4530 \\
\hline $\mathrm{Mg}$ & 196 & 81 & 225 \\
\hline Bulk density, $\mathrm{g} \mathrm{cm}^{-3}$ & 0.77 & 0.90 & 0.34 \\
\hline
\end{tabular}




\section{AGRICULTURAL AND FOOD SCIENCE IN FINLAND}

\section{Vol. 6 (1997): 259-268.}

solution-to-soil ratio of $2.5: 1(\mathrm{v} / \mathrm{v})$. The electrical conductivity of the soil was determined in a water suspension at the solution-to-soil ratio of $2.5: 1$. Exchangeable cations were extracted with four successive portions of $1 \mathrm{M}$ ammonium acetate, pH 7.0 (Thomas 1982). The soil bulk density was determined for air-dry soil compressed as in the experimental pots.

Kick-Brauckmann pots with $7 \mathrm{dm}^{3}$ of soil were used in the pot experiment. A small portion of soil $\left(0.25 \mathrm{dm}^{3}\right)$ was taken from each pot to cover the seed and the rest was fertilized. The treatments were:

Sodium as $\mathrm{Na}_{2} \mathrm{SO}_{4} \cdot 10 \mathrm{H}_{2} \mathrm{O}$ : Potassium as $\mathrm{KCl}$ : AbbreAbbre-

$\begin{array}{lclc}\text { viation: } & \mathrm{mg} \mathrm{dm}^{-3} & \text { viation: } & \mathrm{mg} \mathrm{dm}^{-3} \\ \mathrm{Na}_{0} & 0 & \mathrm{~K}_{0} & 0 \\ \mathrm{Na}_{1} & 200 & \mathrm{~K}_{1} & 100 \\ \mathrm{Na}_{2} & 400 & \mathrm{~K}_{2} & 200\end{array}$

All the nine combinations were made as 5 replicates for each soil. The pots were fertilized also with other elements as analytical grade chemicals at the following rates $\left(\mathrm{mg} \mathrm{dm}^{-3}\right): \mathrm{N}$ as $\mathrm{NH}_{4} \mathrm{NO}_{3}(150), \mathrm{P}$ as $\mathrm{Ca}\left(\mathrm{H}_{2} \mathrm{PO}_{4}\right)_{2} \cdot \mathrm{H}_{2} \mathrm{O}$ (150), $\mathrm{Mg}$ as $\mathrm{MgSO}_{4} \cdot 7 \mathrm{H}_{2} \mathrm{O}(80), \mathrm{S}$ in sulfates of $\mathrm{Mg}, \mathrm{Cu}$, $\mathrm{Mn}, \mathrm{Fe}$ and $\mathrm{Zn}$ (at least 112), $\mathrm{Cu}$ as $\mathrm{CuSO}_{4} \cdot 5 \mathrm{H}_{2} \mathrm{O}$ (4), $\mathrm{Mn}$ as $\mathrm{MnSO}_{4} \cdot \mathrm{H}_{2} \mathrm{O}(4), \mathrm{Fe}$ as $\mathrm{FeSO}_{4} \cdot 7 \mathrm{H}_{2} \mathrm{O}$ (2), $\mathrm{Zn}$ as $\mathrm{ZnSO}_{4} \cdot 7 \mathrm{H}_{2} \mathrm{O}$ (3) and $\mathrm{B}$ as $\mathrm{H}_{3} \mathrm{BO}_{3}$ (2). The seed of timothy ( $300 \mathrm{mg}$ Phleum pratense L. cv. Tuukka) was sown on the fertilized soil and covered with unfertilized soil. Three crops of timothy were harvested. The second and the third crop were fertilized with solutions of $\mathrm{N}$ and $\mathrm{K}$ at the same rates as at the beginning of the experiment. Sodium was applied only at the beginning. The plants were grown outdoors under a glass roof from May to September and watered with deionized water. The first crop was cut 59 days after planting, the second and the third one after 33 days' growth. The plant material was dried at $65^{\circ} \mathrm{C}$ and analyzed for $\mathrm{Ca}, \mathrm{Mg}, \mathrm{Na}$ and $\mathrm{K}$ according to a dry combustion method by Helrich (1990). Potassium and Na were analyzed by flame photometry, $\mathrm{Ca}$ and $\mathrm{Mg}$ by atomic absorption spectroscopy. A known sample was in- cluded in every analysis series. The coefficients of variation ( 23 observations) for the analysis of the sample were: $\mathrm{Na} 17.0 \%$, K $3.6 \%$, Ca $2.9 \%$ and $\mathrm{Mg} 1.1 \%$.

Exchange isotherms were determined for $\mathrm{Na} /$ $\mathrm{Ca}$ and $\mathrm{Na} / \mathrm{K}$ exchange on the three soils by a modified method of Levy et al. (1988). Isotherms were determined using $5 \mathrm{~g}$ of soil ( $2 \mathrm{~g}$ of organogenic soil) in duplicates. The soil samples were first equilibrated with $25 \mathrm{ml}$ of a mixture of solutions of $\mathrm{NaCl}$ and $\mathrm{CaCl}_{2}$ or $\mathrm{NaCl}$ and $\mathrm{KCl}$. Seven different cation equivalent ratios $(0,15$, $30,50,70,85$ or $100 \%$ of $\mathrm{Na}$ ) were used for both isotherms, and the chloride concentration of the first equilibration solution was $0.5 \mathrm{~mol} \mathrm{l}^{-1}$. The suspensions were shaken for $20 \mathrm{~min}$, centrifuged, and the supernatant solution was discarded. This was repeated three times, followed by three similar steps using $50 \mathrm{ml}$ of $0.01 \mathrm{M}$ solutions while maintaining the original $\mathrm{Na} / \mathrm{Ca}$ or $\mathrm{Na} / \mathrm{K}$ ratios. The last $0.01 \mathrm{M}$ solutions were filtered through Schleicher \& Schüll $589^{3}$ (blue ribbon) filter paper and used to determine $\mathrm{Na}$ and $\mathrm{K}$ by flame photometry and $\mathrm{Ca}$ by atomic absorption spectroscopy. The amount of equilibration solution remaining in the soil samples after equilibration was determined by weighing the centrifuge tubes containing the soil and the solution. Thereafter the exchangeable cations adsorbed on the soil samples were determined by three repeated extractions with $30 \mathrm{ml}$ of $1 \mathrm{M}$ ammonium acetate (20 min shaking, centrifuging and filtering through Schleicher \& Schüll $589^{3}$ filter paper). The extracted cations were determined as above. The amount of cations held in the soil by the remaining equilibration solution was deducted from these results.

\section{Results}

The dry matter yields were not affected by $\mathrm{Na}$ treatments. On the organogenic soil, $\mathrm{K}$ fertilization elevated the yields of the second and third harvest by 10 and $51 \%$, respectively $(\mathrm{p}<0.001)$ 


\section{AGRICULTURAL AND FOOD SCIENCE IN FINLAND}

\section{Peltovuori, T. \& Yli-Halla, M. Sodium and potassium fertilization of timothy}

Table 2. Dry matter yields $\left(\mathrm{g} \mathrm{pot}^{-1}\right)$ at the three levels of $\mathrm{K}$ application. Treatments: $\mathrm{K}_{0}=0 \mathrm{mg} \mathrm{dm}^{-3}, \mathrm{~K}_{1}=3 \times 100 \mathrm{mg} \mathrm{dm}^{-3}$, $\mathrm{K}_{2}=3 \times 200 \mathrm{mg} \mathrm{dm}^{-3}$.

\begin{tabular}{lllll}
\hline & Clay & Loam & \multicolumn{2}{c}{ Organogenic soil } \\
Harvest & All K levels & All K levels & $\mathrm{K}_{0}$ & $\mathrm{~K}_{1}$ and $\mathrm{K}_{2}$ \\
\hline I & 15.4 & 16.5 & 23.2 & 23.4 \\
II & 31.5 & 30.0 & 30.0 & 32.9 \\
III & 24.2 & 23.8 & 18.2 & 27.4 \\
Sum & 71.1 & 70.3 & 71.4 & 83.7 \\
\hline
\end{tabular}

(Table 2). Yet, there were no visible $\mathrm{K}$ deficiency symptoms in any treatment of the experiment.

Without $\mathrm{Na}$ and $\mathrm{K}$ application $\left(\mathrm{Na}_{0} \mathrm{~K}_{0}\right)$, the average $\mathrm{Na}$ concentration of timothy (Table 3) was $0.24 \mathrm{~g} \mathrm{~kg}^{-1}$ (range $0.17-0.30 \mathrm{~g} \mathrm{~kg}^{-1}$ ), excluding the plants grown on the clay in the first harvest that had a $\mathrm{Na}$ concentration $\left(0.57 \mathrm{~g} \mathrm{~kg}^{-1}\right)$ deviating from the other corresponding results. When no Na was applied, $\mathrm{K}$ application seemed to elevate the Na concentration but the effect was not statistically significant.

Application of $\mathrm{Na}$ increased the $\mathrm{Na}$ concentration of timothy on all soils and in all harvests $(\mathrm{p}<<0.001)$. The effect was greater for the loam and the organogenic soil than for the clay. The highest $\mathrm{Na}$ concentrations of timothy were reached without $\mathrm{K}$ and with the highest rate of $\mathrm{Na}\left(\mathrm{Na}_{2} \mathrm{~K}_{0}\right)$ in the third harvest: $6.9 \mathrm{~g} \mathrm{~kg}^{-1}$ on the loam and $5.6 \mathrm{~g} \mathrm{~kg}^{-1}$ on the organogenic soil.

Sodium was much weaker than $\mathrm{Ca}$ or $\mathrm{K}$ in competition for cation exchange sites (Fig. 1). In $\mathrm{Na} / \mathrm{K}$ exchange, $\mathrm{Na}$ was least efficient competitor for clay and somewhat more efficient for the two lighter soils. In equimolar equilibrium solution $(\mathrm{Na} / \mathrm{K})$, $\mathrm{Na}$ occupied 24,33 and $38 \%$ of the exchange sites on clay, loam and organogenic soils, respectively. Sodium was even a weaker competitor for exchange sites with $\mathrm{Ca}$ than with $\mathrm{K}$. In an equilibrium solution containing $50 \%$ of both $\mathrm{Na}$ and $\mathrm{Ca}$ (expressed in mmol of charge $\mathrm{dm}^{-3}$ ) there was only $5,4.5$ and less

Table 3. Sodium and potassium concentrations of timothy in the pot experiment ( $\mathrm{g} \mathrm{kg}^{-1}$ dry matter). Treatments: $\mathrm{Na}_{1}=200$ $\mathrm{mg} \mathrm{dm}^{-3}, \mathrm{Na}_{2}=400 \mathrm{mg} \mathrm{dm}^{-3}, \mathrm{~K}_{1}=3 \times 100 \mathrm{mg} \mathrm{dm}^{-3}, \mathrm{~K}_{2}=3 \times 200 \mathrm{mg} \mathrm{dm}^{-3}$.

\begin{tabular}{|c|c|c|c|c|c|c|c|c|c|c|c|}
\hline \multirow{2}{*}{\multicolumn{2}{|c|}{ Harvest }} & & \multicolumn{3}{|l|}{ Clay } & \multicolumn{3}{|l|}{ Loam } & \multicolumn{3}{|c|}{ Organogenic soil } \\
\hline & & & $\mathrm{K}_{0}$ & $\mathrm{~K}_{1}$ & $\mathrm{~K}_{2}$ & $\mathrm{~K}_{0}$ & $\mathrm{~K}_{1}$ & $\mathrm{~K}_{2}$ & $\mathrm{~K}_{0}$ & $\mathrm{~K}_{1}$ & $\mathrm{~K}_{2}$ \\
\hline \multirow{9}{*}{$\mathrm{Na}$} & \multirow{3}{*}{ I } & $\mathrm{Na}_{0}$ & $0.6^{\mathrm{a}}$ & $0.5^{\mathrm{a}}$ & $0.7^{\mathrm{ab}}$ & $0.3^{\mathrm{a}}$ & $0.4^{\mathrm{ab}}$ & $0.5^{\mathrm{ab}}$ & $0.2^{\mathrm{a}}$ & $0.4^{\mathrm{ab}}$ & $0.5^{\mathrm{abc}}$ \\
\hline & & $\mathrm{Na}_{1}$ & $0.7^{\mathrm{ab}}$ & $0.8^{\mathrm{ab}}$ & $1.0^{b c}$ & $1.1^{\mathrm{c}}$ & $1.1^{c}$ & $1.0^{\mathrm{bc}}$ & $1.5^{e}$ & $0.6^{b c}$ & $0.6^{b c}$ \\
\hline & & $\mathrm{Na}_{2}$ & $1.7^{\mathrm{d}}$ & $1.6^{\mathrm{d}}$ & $1.3^{\text {cd }}$ & $2.3^{d}$ & $1.9^{d}$ & $2.0^{\mathrm{d}}$ & $2.2^{f}$ & $1.1^{\mathrm{d}}$ & $0.8^{c}$ \\
\hline & \multirow{3}{*}{ II } & $\mathrm{Na}_{0}{ }_{0}$ & $0.2^{\mathrm{a}}$ & $0.6^{\mathrm{ab}}$ & $1.0^{\text {bcd }}$ & $0.3^{\mathrm{a}}$ & $0.5^{\mathrm{ab}}$ & $0.5^{\mathrm{ab}}$ & $0.3^{a}$ & $0.4^{a b}$ & $0.5^{\mathrm{ab}}$ \\
\hline & & $\mathrm{Na}_{1}$ & $0.6^{\mathrm{ab}}$ & $0.7^{b c}$ & $1.0^{\text {bcd }}$ & $1.5^{\mathrm{cd}}$ & $1.0^{\text {bed }}$ & $0.9^{\mathrm{abc}}$ & $1.8^{\mathrm{d}}$ & $0.6^{\mathrm{b}}$ & $0.5^{\mathrm{ab}}$ \\
\hline & & $\mathrm{Na}_{2}$ & $1.2^{\mathrm{cd}}$ & $1.2^{\mathrm{d}}$ & $1.0^{\text {bod }}$ & $3.5^{e}$ & $1.5^{\mathrm{cd}}$ & $1.6^{\mathrm{d}}$ & $2.8^{e}$ & $1.1^{\mathrm{c}}$ & $0.7^{b}$ \\
\hline & \multirow{3}{*}{ III } & $\mathrm{Na}_{0}{ }_{0}$ & $0.3^{a}$ & $0.4^{a}$ & $0.5^{\mathrm{a}}$ & $0.2^{\mathrm{a}}$ & $0.4^{a}$ & $0.6^{\mathrm{a}}$ & $0.2^{\mathrm{a}}$ & $0.4^{a}$ & $0.5^{\mathrm{a}}$ \\
\hline & & $\mathrm{Na}_{1}$ & $1.1^{\mathrm{bc}}$ & $0.7^{\mathrm{ab}}$ & $0.6^{\mathrm{ab}}$ & $3.2^{\mathrm{c}}$ & $1.2^{\mathrm{ab}}$ & $0.8^{\mathrm{a}}$ & $4.2^{\mathrm{c}}$ & $0.7^{\mathrm{a}}$ & $0.6^{\mathrm{a}}$ \\
\hline & & $\mathrm{Na}_{2}$ & $2.6^{d}$ & $1.6^{\mathrm{c}}$ & $1.2^{\mathrm{bc}}$ & $6.9^{d}$ & $2.6^{\mathrm{bc}}$ & $2.4^{\mathrm{bc}}$ & $5.6^{d}$ & $1.5^{\mathrm{b}}$ & $0.7^{\mathrm{a}}$ \\
\hline \multirow{9}{*}{ K } & \multirow{4}{*}{ I } & $\mathrm{Na}_{0}$ & $45^{\mathrm{a}}$ & $48^{\mathrm{ab}}$ & $50^{\mathrm{ab}}$ & $31^{a}$ & $43^{c}$ & $48^{\text {cde }}$ & $20^{a}$ & $36^{c}$ & $47^{\circ}$ \\
\hline & & $\mathrm{Na}_{1}$ & $45^{a}$ & $47^{a}$ & $49^{\text {ab }}$ & $36^{\mathrm{ab}}$ & $45^{\text {cde }}$ & $49^{c}$ & $25^{b}$ & $40^{d}$ & $50^{f}$ \\
\hline & & $\mathrm{Na}_{2}$ & $45^{\mathrm{a}}$ & $48^{\mathrm{ab}}$ & $53^{b}$ & $37^{b}$ & $44^{\text {cd }}$ & $49^{\text {de }}$ & $26^{b}$ & $38^{\mathrm{cd}}$ & $50^{f}$ \\
\hline & & $\mathrm{Na}_{0}$ & $31^{a}$ & $42^{b}$ & $45^{\mathrm{b}}$ & $13^{a}$ & $34^{c}$ & $41^{d}$ & $10^{a}$ & $26^{b}$ & $40^{c}$ \\
\hline & \multirow[t]{3}{*}{ II } & $\mathrm{Na}_{1}$ & $32^{a}$ & $43^{b}$ & $44^{b}$ & $17^{\mathrm{b}}$ & $35^{c}$ & $41^{\mathrm{d}}$ & $11^{\mathrm{a}}$ & $29^{b}$ & $42^{c}$ \\
\hline & & $\mathrm{Na}_{2}$ & $33^{a}$ & $42^{b}$ & $45^{b}$ & $19^{b}$ & $34^{c}$ & $45^{e}$ & $10^{a}$ & $27^{b}$ & $42^{c}$ \\
\hline & & $\mathrm{Na}_{0}$ & $21^{a}$ & $42^{c}$ & $50^{c}$ & $12^{\mathrm{a}}$ & $35^{b}$ & $47^{c}$ & $9^{a}$ & $31^{\mathrm{b}}$ & $46^{c}$ \\
\hline & \multirow[t]{2}{*}{ III } & $\mathrm{Na}_{1}$ & $23^{\mathrm{ab}}$ & $45^{\mathrm{d}}$ & $48^{e}$ & $13^{a}$ & $37^{b}$ & $47^{c}$ & $9^{a}$ & $32^{b}$ & $48^{c}$ \\
\hline & & $\mathrm{Na}_{2}$ & $24^{b}$ & $42^{c}$ & $49^{\circ}$ & $14^{a}$ & $36^{\mathrm{b}}$ & $46^{c}$ & $8^{a}$ & $31^{b}$ & $46^{c}$ \\
\hline
\end{tabular}

Each soil and harvest was tested separately. Means with same superscripts do not differ at $\mathrm{p}=0.05$. 
Vol. 6 (1997): 259-268.

than $3 \%$ of exchange sites occupied by $\mathrm{Na}$ on clay, loam and organogenic soils, respectively.

Application of $\mathrm{K}$ drastically depressed the effect of $\mathrm{Na}$ fertilization $(\mathrm{p}<0.001)$ even though added $\mathrm{K}$ was more likely to be bound on the cation exchange sites than $\mathrm{Na}$. In the $\mathrm{Na} / \mathrm{K}$ exchange, $\mathrm{K}$ was least efficient competitor on the organogenic soil, and the effect of $\mathrm{K}$ was strongest on this soil; $\mathrm{K}_{2}$ application decreased the $\mathrm{Na}$ concentration of timothy at the $\mathrm{Na}_{2}$ level in the third harvest to one-eighth of that obtained without $\mathrm{K}$ application (Table 3). When plants were fertilized with $\mathrm{K}$, the targeted $\mathrm{Na}$ concentration of $2 \mathrm{~g} \mathrm{~kg}^{-1}$ was reached only with the higher $\mathrm{Na}$ level in the third harvest on the loam. The sodium concentration of timothy increased most effectively when the $\mathrm{K}$ concentration of the plants decreased to or below $15 \mathrm{~g} \mathrm{~kg}^{-1}$ (Fig. 2). These concentrations, suggesting $\mathrm{K}$ deficiency, occurred in plants grown without $\mathrm{K}$ application in the second and third harvest on the organogenic soil and in the third harvest on the loam.

Application of $\mathrm{Na}$ did not decrease the concentration of $\mathrm{K}$ in timothy at any $\mathrm{K}$ level. Figure 3 demonstrates the abundance of $\mathrm{K}$ compared to other cations in the plants fertilized with the same amounts $\left(\mathrm{mg} \mathrm{dm}^{-3}\right)$ of $\mathrm{Na}$ and $\mathrm{K}$. When expressed in $\mathrm{mol} \mathrm{dm}^{-3}$, the plants received more $\mathrm{Na}$ than K. Despite the similar amounts added as fertilizer, the first harvest of timothy grown on mineral soils took 50 times and timothy grown on the organogenic soil 80 times more $\mathrm{K}$ than $\mathrm{Na}$. A tenfold increase in $\mathrm{Na}$ concentration from the $\mathrm{Na}_{0}$ level with an equivalent decrease in $\mathrm{K}$ concentration would theoretically lower the $\mathrm{K}$ concentration by only about $4 \mathrm{~g} \mathrm{~kg}^{-1}$ at the most. Not even this effect seems to be feasible.

Sodium application decreased the Ca concentration of timothy on all soils and for all harvests $(\mathrm{p}<0.001)$. The mean $\mathrm{Ca}$ concentrations were $8.5,7.2$ and $6.6 \mathrm{~g} \mathrm{~kg}^{-1}$ in the treatments $\mathrm{Na}_{0}$, $\mathrm{Na}_{1}$ and $\mathrm{Na}_{2}$, respectively. In the third harvest on the organogenic soil, the $\mathrm{Ca}$ concentration of timothy was as much as $35 \%$ lower in the $\mathrm{Na}_{2} \mathrm{~K}_{0}$ $\left(10.7 \mathrm{~g} \mathrm{~kg}^{-1}\right)$ than in the $\mathrm{Na}_{0} \mathrm{~K}_{0}\left(16.5 \mathrm{~g} \mathrm{~kg}^{-1}\right)$ treatment. Sodium application did not influence the $\mathrm{Mg}$ concentrations which, owing to $\mathrm{Mg}$ fertili-
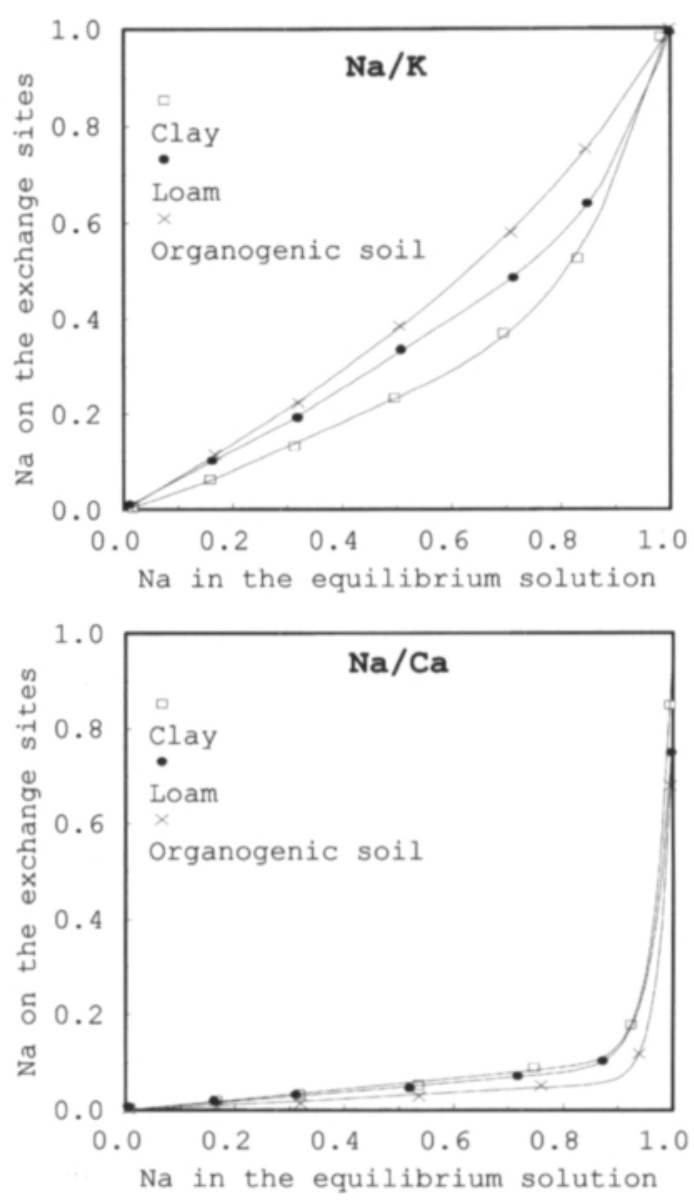

Fig. 1. Cation exchange isotherms for the cation pairs $\mathrm{Na}$ / $\mathrm{K}$ and $\mathrm{Na} / \mathrm{Ca}$. Sodium on the exchange sites and in the equilibrium solution expressed as a fraction of total positive charge.

zation, were rather high in the experiment. Potassium application strongly lowered the $\mathrm{Mg}$ concentration of timothy $(\mathrm{p}<<0.001)$. The average $\mathrm{Mg}$ concentration was $4.6,3.1$ and $2.6 \mathrm{~g} \mathrm{~kg}^{-1}$ in the treatments $\mathrm{K}_{0}, \mathrm{~K}_{1}$ and $\mathrm{K}_{2}$, respectively.

One of the aims of $\mathrm{Na}$ fertilization has been to decrease the excessive concentration of $\mathrm{K}$ in herbage and thus to decrease the $\mathrm{K} /(\mathrm{Ca}+\mathrm{Mg})$ ratio of fodder. In the present study, $\mathrm{Na}$ fertilization, on the contrary, increased the ratio $(\mathrm{p}<0.001)$ because it decreased the $\mathrm{Ca}$ concentration but did not affect the $\mathrm{K}$ and $\mathrm{Mg}$ concen- 
Peltovuori, T. \& Yli-Halla, M. Sodium and potassium fertilization of timothy

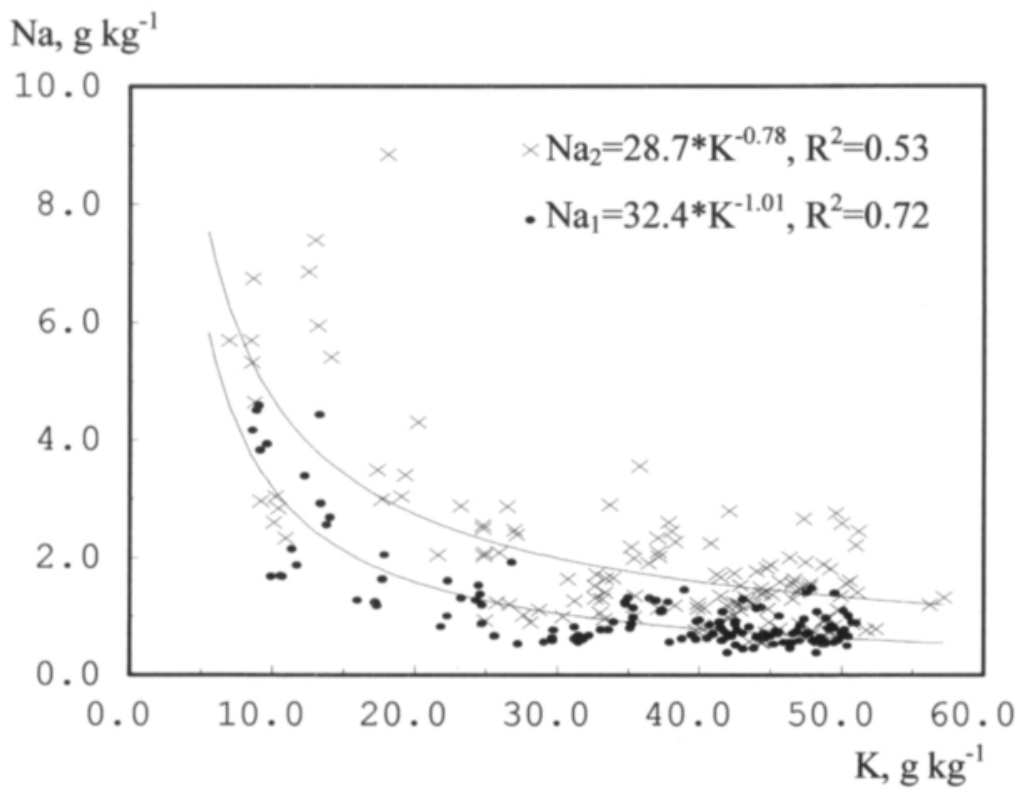

Fig. 2. Relationship of the concentrations of $\mathrm{Na}$ and $\mathrm{K}$ of timothy fertilized with two $\mathrm{Na}$ levels $\left(\mathrm{Na}_{1}=\right.$ $\left.200 \mathrm{mg} \mathrm{dm}^{-3}, \mathrm{Na}_{2}=400 \mathrm{mg} \mathrm{dm}^{-3}\right)$. trations (Table 4). However, the $\mathrm{K} /(\mathrm{Ca}+\mathrm{Mg})$ ratios remained below 2.5 in all treatments, and the unfavourable effect of $\mathrm{Na}$ diminished towards the end of the experiment. Without $\mathrm{K}$ application $\left(\mathrm{K}_{0}\right)$ the $\mathrm{K} /(\mathrm{Ca}+\mathrm{Mg})$ ratios decreased to very low values in the third harvest (range $0.2-0.8$ ). Potassium had a strong enhancing effect on the ratio $(\mathrm{p}<<0.001)$ throughout the experiment. Sodium fertilization lowered the $\mathrm{K} / \mathrm{Na}$ ratios in

mmol (+) $\mathrm{kg}^{-1}$

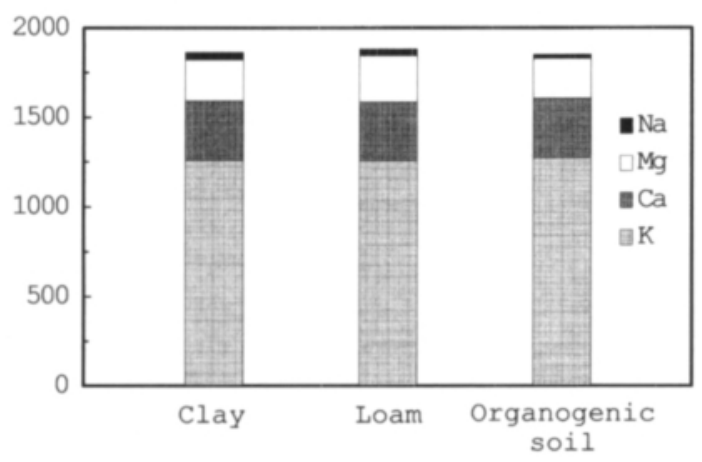

Fig. 3. $\mathrm{Na}, \mathrm{K}, \mathrm{Ca}$ and $\mathrm{Mg}$ concentrations of timothy (mmol of charge $\mathrm{kg}^{-1}$ ) in the first harvest. The plants received similar $\mathrm{Na}$ and $\mathrm{K}$ fertilization ( $200 \mathrm{mg} \mathrm{dm}^{-3}$, treatment $\mathrm{Na}_{1} \mathrm{~K}_{2}$ ). the plants $(\mathrm{p}<<0.001)$ which is considered to improve the quality of fodder.

In the $\mathrm{Na}_{0} \mathrm{~K}_{0}$ pots, $22-34 \%$ of the native exchangeable $\mathrm{Na}$ was taken up by plants while in the $\mathrm{Na}_{0} \mathrm{~K}_{2}$ pots, $52-71 \%$ was taken up. However, the reserves of exchangeable Na were not depleted during the experiment in clay while there was a consistent decrease in the organogenic soil and inconsistent changes in the loam (Table 5). Applied Na elevated the concentration of exchangeable $\mathrm{Na}$ in the soil to very high levels. At the end of the pot experiment, Na extracted from the soils of the highest $\mathrm{Na}$ treatment represented 11,14 and $6 \%$ of all extracted cations (mol of charge $\mathrm{dm}^{-3}$ ) in clay, loam and organogenic soils, respectively. The heavy fertilization also elevated the electrical conductivities of the soils. The maximum values at the end of the experiment, measured in the $\mathrm{Na}_{2} \mathrm{~K}_{2}$ pots, were $0.8,0.6$ and $1.0 \mathrm{dS} \mathrm{m}^{-1}$ in clay, loam and organogenic soils, respectively.

In pots fertilized with $\mathrm{K}$, the apparent utilization of added $\mathrm{Na}$ was less than $4 \%$ on all soils and at the $\mathrm{K}_{2}$ level it remained below $0.8 \%$ for the clay and the organogenic soil. At the $\mathrm{K}_{0}$ lev$\mathrm{el}$, the utilization of $\mathrm{Na}$ was somewhat higher 
Vol. 6 (1997): 259-268.

Table 4. $\mathrm{K} /(\mathrm{Ca}+\mathrm{Mg})$ ratios $\left(\mathrm{mol}\right.$ of charge $\mathrm{kg}^{-1}$ ) of timothy in the pot experiment. Treatments: $\mathrm{Na}_{1}=200 \mathrm{mg} \mathrm{dm}^{-3}$, $\mathrm{Na}_{2}=400 \mathrm{mg} \mathrm{dm}^{-3}, \mathrm{~K}_{1}=3 \times 100 \mathrm{mg} \mathrm{dm}^{-3}, \mathrm{~K}_{2}=3 \times 200 \mathrm{mg} \mathrm{dm}^{-3}$.

\begin{tabular}{|c|c|c|c|c|c|c|c|c|c|c|}
\hline \multirow[b]{2}{*}{ Harvest } & & \multicolumn{3}{|l|}{ Clay } & \multicolumn{3}{|c|}{ Loam } & \multicolumn{3}{|c|}{ Organogenic soil } \\
\hline & & $\mathrm{K}_{0}$ & $\mathrm{~K}_{1}$ & $\mathrm{~K}_{2}$ & $\mathrm{~K}_{0}$ & $\mathrm{~K}_{1}$ & $\mathrm{~K}_{2}$ & $\mathrm{~K}_{0}$ & $\mathrm{~K}_{1}$ & $\mathrm{~K}_{2}$ \\
\hline \multirow{3}{*}{ I } & $\mathrm{Na}_{0}$ & $1.8^{\mathrm{a}}$ & $2.0^{b}$ & $2.1^{b c}$ & $1.1^{\mathrm{a}}$ & $1.6^{\mathrm{b}}$ & $1.9^{\mathrm{c}}$ & $0.6^{\mathrm{a}}$ & $1.4^{\mathrm{c}}$ & $2.1^{e}$ \\
\hline & $\mathrm{Na}_{1}$ & $2.1^{\text {bod }}$ & $2.2^{\text {cd }}$ & $2.3^{\text {cde }}$ & $1.5^{b}$ & $2.0^{\mathrm{cd}}$ & $2.1^{\mathrm{de}}$ & $0.9^{b}$ & $1.7^{\mathrm{d}}$ & $2.3^{f}$ \\
\hline & $\mathrm{Na}_{2}$ & $2.2^{\mathrm{cd}}$ & $2.3^{\text {de }}$ & $2.5^{e}$ & $1.8^{c}$ & $2.3^{e f}$ & $2.5^{f}$ & $0.9^{b}$ & $1.8^{\mathrm{d}}$ & $2.5^{8}$ \\
\hline \multirow{3}{*}{ II } & $\mathrm{Na}_{0}$ & $1.2^{\mathrm{a}}$ & $2.1^{\mathrm{c}}$ & $2.3^{\mathrm{d}}$ & $0.4^{\mathrm{a}}$ & $1.4^{\mathrm{c}}$ & $1.9^{e}$ & $0.2^{\mathrm{a}}$ & $1.0^{b}$ & $2.0^{\mathrm{d}}$ \\
\hline & $\mathrm{Na}_{1}$ & $1.5^{b}$ & $2.3^{d}$ & $2.3^{d}$ & $0.6^{\mathrm{ab}}$ & $1.6^{d}$ & $2.0^{\circ}$ & $0.3^{a}$ & $1.2^{\mathrm{c}}$ & $2.3^{\mathrm{e}}$ \\
\hline & $\mathrm{Na}_{2}$ & $1.6^{\mathrm{b}}$ & $2.2^{\text {cd }}$ & $2.3^{\mathrm{d}}$ & $0.7^{b}$ & $1.7^{\mathrm{d}}$ & $2.3^{f}$ & $0.3^{a}$ & $1.1^{\mathrm{bc}}$ & $2.3^{e}$ \\
\hline \multirow{3}{*}{ III } & $\mathrm{Na}_{0}$ & $0.6^{\mathrm{a}}$ & $1.7^{\mathrm{b}}$ & $2.2^{\mathrm{d}}$ & $0.3^{\mathrm{a}}$ & $1.2^{b}$ & $1.8^{\mathrm{d}}$ & $0.2^{a}$ & $1.1^{\mathrm{b}}$ & $2.1^{\mathrm{c}}$ \\
\hline & $\mathrm{Na}_{1}$ & $0.8^{\mathrm{a}}$ & $2.0^{\text {cd }}$ & $2.2^{\mathrm{d}}$ & $0.4^{a}$ & $1.4^{b c}$ & $1.8^{\mathrm{d}}$ & $0.2^{\mathrm{a}}$ & $1.2^{\mathrm{b}}$ & $2.4^{d}$ \\
\hline & $\mathrm{Na}_{2}$ & $0.8^{\mathrm{a}}$ & $1.9^{b c}$ & $2.2^{\mathrm{d}}$ & $0.4^{a}$ & $1.4^{\mathrm{c}}$ & $2.1^{\circ}$ & $0.2^{\mathrm{a}}$ & $1.2^{\mathrm{b}}$ & $2.3^{\mathrm{d}}$ \\
\hline
\end{tabular}

Each soil and harvest was tested separately. Means with same superscripts do not differ at $\mathrm{p}=0.05$.

$(8-11 \%)$ for the loam and the organogenic soil but for the clay it was below $4 \%$ in all treatments. By way of comparison, utilization of added $\mathrm{K}$ was $68-75 \%$ for the organogenic soil, $34-64 \%$ for the loam and $21-45 \%$ for the clay. The reserves of soil $\mathrm{K}$ decreased at the $\mathrm{K}_{0}$ and $\mathrm{K}_{1}$ levels for all the soils, for the organogenic soil also at the higher application rate $\left(\mathrm{K}_{2}\right)$ (Table 5). The

Table 5. Exchangeable $\mathrm{Na}$ and $\mathrm{K}$ concentrations of the experimental soils $\left(\mathrm{mg} \mathrm{dm}^{-3}\right)$ before and after the pot experiment.

\begin{tabular}{|c|c|c|c|c|c|}
\hline & Original & After the experiment & $\mathrm{K}_{0}$ & $\mathrm{~K}_{1}$ & $\mathrm{~K}_{2}$ \\
\hline \multicolumn{6}{|l|}{$\mathrm{Na}$} \\
\hline Clay & 15 & $\begin{array}{l}\mathrm{Na}_{0} \\
\mathrm{Na}_{1} \\
\mathrm{Na}_{2}\end{array}$ & $\begin{array}{r}18 \\
208 \\
364\end{array}$ & $\begin{array}{r}14 \\
174 \\
353\end{array}$ & $\begin{array}{r}13 \\
191 \\
543\end{array}$ \\
\hline Loam & 8 & $\begin{array}{l}\mathrm{Na}_{0} \\
\mathrm{Na}_{1} \\
\mathrm{Na}_{2}\end{array}$ & $\begin{array}{r}4 \\
189 \\
325\end{array}$ & $\begin{array}{r}10 \\
211 \\
430\end{array}$ & $\begin{array}{r}14 \\
253 \\
352\end{array}$ \\
\hline $\begin{array}{l}\text { Organogenic } \\
\text { soil }\end{array}$ & 9 & $\begin{array}{l}\mathrm{Na}_{0} \\
\mathrm{Na}_{1} \\
\mathrm{Na}_{2}\end{array}$ & $\begin{array}{r}3 \\
132 \\
276\end{array}$ & $\begin{array}{r}5 \\
168 \\
325\end{array}$ & $\begin{array}{r}4 \\
195 \\
353\end{array}$ \\
\hline \multicolumn{6}{|l|}{ K } \\
\hline Clay & 283 & $\begin{array}{l}\mathrm{Na}_{0} \\
\mathrm{Na}_{1} \\
\mathrm{Na}_{2}\end{array}$ & $\begin{array}{l}78 \\
78 \\
83\end{array}$ & $\begin{array}{l}172 \\
152 \\
130\end{array}$ & $\begin{array}{l}256 \\
310 \\
313\end{array}$ \\
\hline Loam & 134 & $\begin{array}{l}\mathrm{Na}_{0} \\
\mathrm{Na}_{1} \\
\mathrm{Na}_{2}\end{array}$ & $\begin{array}{l}32 \\
27 \\
27\end{array}$ & $\begin{array}{l}58 \\
60 \\
45\end{array}$ & $\begin{array}{l}163 \\
194 \\
240\end{array}$ \\
\hline $\begin{array}{l}\text { Organogenic } \\
\text { soil }\end{array}$ & 87 & $\begin{array}{l}\mathrm{Na}_{0} \\
\mathrm{Na}_{1} \\
\mathrm{Na}_{2}\end{array}$ & $\begin{array}{l}19 \\
19 \\
23\end{array}$ & $\begin{array}{l}33 \\
32 \\
30\end{array}$ & $\begin{array}{l}66 \\
55 \\
69\end{array}$ \\
\hline
\end{tabular}


total uptake of $\mathrm{K}$ by plants (three harvests) at the $\mathrm{K}_{0}$ level was 325,199 and $145 \mathrm{mg} \mathrm{dm}^{-3}$ for clay, loam and organogenic soil, of which 120 , 89 and $76 \mathrm{mg} \mathrm{dm}^{-3}$ was non-exchangeable $\mathrm{K}$, respectively.

\section{Discussion}

The Na concentration of timothy not fertilized with $\mathrm{Na}$ was up to 10 times higher in the present pot experiment than generally found in field conditions in Finland (Kähäri and Nissinen 1978, Jansson 1986) even though the experimental soils had an average $\mathrm{Na}$ status as compared to the soils of Finland (Sippola and Tares 1978). The high $\mathrm{Na}$ concentrations can partly be explained by a high $\mathrm{N}$ fertilization rate $\left(450 \mathrm{mg} \mathrm{dm}^{-3}\right.$ corresponding to $900 \mathrm{~kg} \mathrm{ha}^{-1}$ ). In field conditions, $\mathrm{N}$ fertilization of $600 \mathrm{~kg} \mathrm{ha}^{-1}$ has increased the $\mathrm{Na}$ concentration of mixed ley by a factor of 6.7 as compared to unfertilized ley (Rinne et al. 1974). Due to the high Na concentrations of timothy in the present pot experiment, the results cannot be applied quantitatively to field conditions, but they give qualitative information about the different interactions between cations in the nutrition of timothy. In normal cultivation the plants are better supplied with $\mathrm{K}$ than in the $\mathrm{K}_{0}$ pots of the present experiment. Therefore, the response of timothy to $\mathrm{Na}$ fertilization in field conditions would most likely be closer to that observed at the $K_{1}$ and $K_{2}$ levels and far from the higher responses measured in the $\mathrm{K}_{0}$ pots.

The increased $\mathrm{Na}$ concentration of timothy caused by the application of $\mathrm{K}$ at the $\mathrm{Na}_{0}$ level can be explained by cation exchange. Added K effectively displaces $\mathrm{Na}$ from the cation exchange sites of soil, as was shown in the $\mathrm{Na} / \mathrm{K}$ exchange studies. A higher $\mathrm{Na}$ concentration in the soil solution consequently promotes $\mathrm{Na}$ uptake by timothy. However, the observed increase of $\mathrm{Na}$ concentration brought about by $\mathrm{K}$ application is marginal. The slight increase in plant $\mathrm{K}$ concentration upon $\mathrm{Na}$ addition in the $\mathrm{K}_{0}$ treat- ment on loam and organogenic soil reflects the exchange between added $\mathrm{Na}$ and soil $\mathrm{K}$.

Calcium is the dominating exchangeable cation in the soil, and the $\mathrm{Na} / \mathrm{Ca}$ exchange equilibria suggest that added $\mathrm{Na}$ remained nearly completely in the soil solution. The particularly high selectivity for $\mathrm{Ca}$ of the organogenic soil is probably due to the complexation of $\mathrm{Ca}$ with the functional groups of organic matter (McBride 1994). In spite of the lowest selectivity for $\mathrm{Na}$ over $\mathrm{Ca}$ in the organogenic soil, the highest $\mathrm{Na}$ concentrations were obtained on the loam. At the end of the experiment the percentage of $\mathrm{Na}$ of the sum of cations (in mol of charge $\mathrm{dm}^{-3}$ ) extracted by ammonium acetate was highest in the loam, the $\mathrm{Na}$ activity of the soil solution consequently being highest in this soil. The difference in $\mathrm{Na}$ activity in the soil solution may thus explain the difference in the $\mathrm{Na}$ concentration of timothy grown on the mineral and the organogenic soils. The high original $\mathrm{Ca}$ concentration of the organogenic soil may also have depressed the uptake of $\mathrm{Na}$ through cation antagonism. In $\mathrm{K}$ uptake the selectivity by plants seemed to dominate the selectivity in cation exchange. The difference in $\mathrm{Na}$ concentrations between the mineral soils is due to the larger reserves of $\mathrm{K}$ in clay.

Indeed, the most pronounced phenomenon in the present study was the dependence of Na uptake on the $\mathrm{K}$ supply, either in the form of native or added $\mathrm{K}$. The effect of $\mathrm{Na}$ application on $\mathrm{Na}$ concentration of timothy for the three soils (organogenic soil $\gtrsim$ loam $>$ clay) was at odds with the $\mathrm{K}$ supplying power of the soils. The effect of the lower $\mathrm{K}$ supplying power of organogenic soils on the Na concentration of timothy was also evident in the study of Kähäri and Nissinen (1978). They reported higher Na concentrations of timothy in the province of Lappi, dominated by organogenic and coarse mineral soils, than in the rest of the country. They also observed that timothy grown on Sphagnum peat soils contained $122 \mathrm{mg} \mathrm{Na} \mathrm{kg}^{-1}$ in contrast to the average around $50 \mathrm{mg} \mathrm{kg}^{-1}$ in timothy grown on other soils, without a marked difference in exchangeable $\mathrm{Na}$ in soil. 


\section{AGRICULTURAL AND FOOD SCIENCE IN FINLAND}

Vol. 6 (1997): 259-268.

The increasing efficiency of $\mathrm{Na}$ fertilization towards the end of the experiment can, besides a decrease of the reserves of soil $\mathrm{K}$ upon $\mathrm{K}$ uptake by the plants, partly be caused by gradual filling of storage capacity for $\mathrm{Na}$ in roots and consequent transport of $\mathrm{Na}$ to shoots. Distinctively natrophobic timothy stores as much as $90 \%$ of $\mathrm{Na}$ taken up in the roots (Jarvis 1982). When this storage capacity is used up, the Na concentration of the shoots starts to increase. It has indeed been observed that the Na concentration of timothy increases when plants age (Jarvis 1982). The same phenomenon, in a weaker form, has been observed with perennial ryegrass, meadow fescue and cocksfoot (Rinne et al. 1974, Smith et al. 1980).

The effect of $\mathrm{Na}$ fertilization on the Ca concentration and $\mathrm{K} /(\mathrm{Ca}+\mathrm{Mg})$ ratio of timothy was opposite to that observed with perennial ryegrass in field conditions (Chiy and Phillips 1993). However, in Chiy and Phillips' experiment, considerably natrophilic ryegrass was grown in suboptimal K conditions: $\mathrm{Na}$ fertilization increased the Na concentration of herbage substantially, increased the yield and $\mathrm{Ca}$ concentration and even lowered the $\mathrm{K}$ concentration of herbage. The apparent recovery of $\mathrm{Na}$ by ryegrass in that field experiment was $70 \%$, which is considerably higher than in the present pot experiment. The difference between timothy and ryegrass supplied adequately with $\mathrm{K}$ would probably be smaller than these results suggest.

\section{Conclusions}

The present study shows that timothy has such a preference for $\mathrm{K}$ that even an excessive $\mathrm{K}$ concentration in a plant cannot be suppressed by ample $\mathrm{Na}$ additions. The strong reduction of $\mathrm{Na}$ uptake by native and added $\mathrm{K}$ makes it difficult to elevate the $\mathrm{Na}$ concentration of timothy sward by $\mathrm{Na}$ applications in practice. As long as $\mathrm{K}$ concentration of timothy is at a level sufficient for maximum growth or higher (luxury consumption), the Na concentration of shoots cannot be effectively increased by $\mathrm{Na}$ application. It is possible to elevate the $\mathrm{Na}$ concentration of timothy substantially only when plants are in $\mathrm{K}$ deficiency. However, a deficiency of K endangers the production of maximum yield and it may be unreasonable to produce grass high in $\mathrm{Na}$ at the expense of the yield. If $\mathrm{Na}$ is applied to timothy in field conditions, the utilization rate cannot be expected to be high. Other grass species like cocksfoot and ryegrass utilize Na more effectively (Smith et al. 1980, Jarvis 1982). Cultivation of these less natrophobic species as pure stands or as mixtures with timothy is a more realistic alternative to elevate the $\mathrm{Na}$ content of forage than $\mathrm{Na}$ fertilization of timothy.

Acknowledgement. The authors wish to thank Kemira Agro Oy for a grant for carrying out this study.

\section{References}

Chiy, P.C. \& Phillips, C.J. 1993. Sodium fertilizer application to pasture. 1. Direct and residual effects on pasture production and composition. Grass and Forage Science 48: 189-202.

- , Phillips, C.J. \& Bello, M.R. 1993. Sodium fertilizer application to pasture. 2. Effects on dairy cow production and behaviour. Grass and Forage Science 48: 203-212.

Ettala, E. \& Kossila, V. 1979. Mineral content in heavily nitrogen fertilized grass and its silage. Annales Agriculturae Fenniae 18: 252-262.

Flowers, T. J. \& Läuchli, A. 1983. Sodium versus potassi- um: Substitution and compartmentation. In: Läuchli, A. \& Bieleski, R. L. (eds.). Encyclopedia of Plant Physiology, New Series Vol. 15B: 651-681. Berlin and New York, Springer-Verlag.

Helrich, K. 1990. Official methods of analysis. 15. ed. Arlington, The Association of Official Analytical Chemists. $639 \mathrm{p}$.

Horn, G. 1988. Experiences with 'Magnesia-Kainit' on grassland. Journal of the Science of Food and Agriculture 43: 324.

Jansson, H. 1986. Sodium contents of different plant species grown side by side. Annales Agriculturae 


\title{
Peltovuori, T. \& Yli-Halla, M. Sodium and potassium fertilization of timothy
}

Fenniae 25: 273-277.

Jarvis, S.C. 1982. Sodium absorption and distribution in forage grasses of different potassium status. Annals of Botany (London) 49: 199-206.

Kähäri, J. \& Nissinen, H. 1978. The mineral element contents of timothy (Phleum pratense L.) in Finland: I. The elements calcium, magnesium, phosphorus, potassium, chromium, cobalt, iron, manganese, sodium and zinc. Acta Agriculturae Scandinavica, Supplement 20: 26-39.

Leigh, R.A., Gorham, J. \& Wyn Jones, R.G. 1988. The cellular and genetic basis for cation discrimination by plants. Journal of the Science of Food and Agriculture 43: 319-320.

Levy, G.J., Watt, H. v.H. van der, Shainberg, I. \& Du Plessis, H.M. 1988. Potassium-calcium and sodium-calcium exchange on kaolinite and kaolinitic soils. Soil Science Society of America Journal 52: 1259-1264.

McBride, M.B. 1994. Environmental Chemistry of Soils. New York, Oxford University Press. 406 p.

Mundy, G.N. 1983. Effects of potassium and sodium concentrations on growth and cation accumulation in pasture species grown in sand culture. Australian Journal of Agricultural Research 34: 469-481.

NJF. 1975. Förslag till normer för makro- och mikrominelarer till nötkreatur och svin. Foderjournalen 3-4: 55-103.

Nowakowski, T.Z., Bolton, J. \& Byers, M. 1974. Effects of replacing potassium by sodium on growth and on inorganic and organic composition of Italian ryegrass. Journal of the Science of Food and Agriculture 25: 271-283.

Rinne, S.-L., Sillanpää, M., Huokuna, E. \& Hiivola, S.-L. 1974. Effects of heavy nitrogen fertilization on iron, manganese, sodium, zinc, copper, strontium, molybdenum and cobalt contents in ley grasses. Annales Agriculturae Fenniae 13: 109-118.

Sippola, J. \& Tares, T. 1978. The soluble content of mineral elements in cultivated Finnish soils. Acta Agriculturae Scandinavica, Supplement 20: 11-25.

Smith, F.W. 1974. The effect of sodium on potassium nutrition and ionic relations in Rhodes grass. Australian Journal of Agricultural Research 25: 407-414.

Smith, G.S. \& Middleton, K.R. 1978. Sodium and potassium content of topdressed pastures in New Zealand in relation to plant and animal nutrition. New Zealand Journal of Experimental Agriculture 6: 217-225.

- , Middleton, K.R. \& Edmonds, A.S. 1980. Sodium nutrition of pasture plants. II. Effect of sodium chloride on growth, chemical composition and reduction of $\mathrm{ni}$ trate nitrogen. New Phytologist 84: 613-622.

Thomas, G.W. 1982. Exchangeable cations. In: Page, A.L. et al. (eds.). Methods of Soil Analysis. Madison, Wisconsin, American Society of Agronomy. Agronomy 9, 2: 159-164.

\section{SELOSTUS}

\section{Timotein natriumlannoitus}

\author{
Tommi Peltovuori ja Markku Yli-Halla \\ Helsingin yliopisto
}

Suomessa nurmikasvien natriumpitoisuus on paljon pienempi kuin lypsykarjan rehun pitoisuudeksi suositellaan. Nurmirehun Na-pitoisuuden kohottaminen parantaisi sen ravitsemuksellista laatua ja lisäisi joidenkin tutkimuksien mukaan rehun maittavuutta. Erityisen vähän natriumia on timoteissä. Astiakokeessa selvitettiin $\mathrm{Na}$-lannoituksen $\left(0,200\right.$ tai $400 \mathrm{mg} \mathrm{l}^{-1}$ kokeen alussa) vaikutusta timotein $\mathrm{Na}-, \mathrm{K}-, \mathrm{Ca}-\mathrm{ja}$ Mg-pitoisuuteen ja K-lannoituksen (0, 100 tai $200 \mathrm{mg}$ $\mathrm{I}^{-1}$ jokaiselle korjatulle sadolle) vaikutusta Na-lannoituksen tehoon kolmella eri maalajilla.

Natriumlannoitus ei vaikuttanut timotein kuivaainesatoon, mutta se kohotti timotein Na-pitoisuutta selvästi kaikilla maalajeilla ja kaikissa korjatuissa sadoissa. Hieta- ja turvemailla vaikutus oli voimak- kaampaa kuin savimaalla. Kaliumlannoitus ja maan suuri K-pitoisuus heikensivät Na-lannoituksen tehoa erittäin voimakkaasti. Natriumlannoitus toimi tehokkaimmin, kun timotein K-pitoisuus laski lähelle puutostilaa (alle $15 \mathrm{~g} \mathrm{~kg}^{-1}$ ). Näin pieniin $\mathrm{K}$-pitoisuuksiin päästiin vain ilman K-lannoitusta kasvaneissa koejäsenissä hieta- ja turvemailla. Natriumlannoitus pienensi jonkin verran timotein Ca-pitoisuutta, mutta ei K- eikä $\mathrm{Mg}$-pitoisuutta. Natriumlannoituksen näennäinen hyväksikäyttöaste oli kaikilla mailla alle $4 \%$. Natriumia timoteitä tehokkaammin ottavien nurmikasvilajien (koiranheinä, raiheinä) viljely saattaa olla timotein $\mathrm{Na}$-lannoitusta parempi keino nurmirehun Na-pitoisuuden kohottamiseksi. 